\section{8 シンポ}

脳随自体の損鹪飞関しては，このような外力では王倒 的飞 coup injury が多く, その場合の特徴な損傷が比 較的深くまで及ぶことである。もちろんこれは重症の場 合であり，臨床上何日も意識障害が続く。逆億識消失 が数時間以内で回復すれば，脳には少なくとす問題にな るような挫創を生してていない。

頭蓋骨損傷関しては，顔面・頭蓋底骨折䎲ともなう 随液漏・気脳症ひき続いて喣膜资が問題になる。

合併してくる外傷として，額部損賃も忘れてはならな いが，外傷性視神経損傷儿よる失明むまた，脳神経外科 領域で関心の持たれるとこるである。

\section{䟧骨々折の診断・治療上の問題点}

\section{大阪市大耳鼻科}

前川 彦右衛門

耳鼻咽唉科の臨床を訪ねる顔面外傷のうち最も頻度の 高い舅骨々折については，その診断と治潦に関して既に 多くの業績が重私られている。私标，診療上若干の問題
点と考えられる事項をとりあげて検討を加えたい。

1) レ線䛦断上の問題

本症の竞断に適したレ線険查法については既に定訬 あるが，正常例炕括いてあしばしば病的所見と疑わし 像を呈することがある。この観点から読影上の問題点 中心湌討したい。

2）治療上の問題

本症の新鮮例仗対する非微血的整復術は容易に最好 結果を得ることができるが，時化は患者は術後な赫不 を訴えるすのすある。道跡調査炕より自，他觉症状を 察すること飞より, 手術時期, 整復法, 麻酔方法, 固 法との関係, 更には外賃性神経症との関連などについ 検討したい。

3）陳旧例炕ついて

小数例ではあるが，自験例を中心陳旧性鼻骨々折 よる変形飞対する治痖飞触たい。

4）小児炕括ける鼻骨々折沉ついての問題

彰断がしばしば困難である小児の骨折について，彰 上の問題点と共に，術後の遠隔成續飞招いて問題がな かぞうか検討したい。 